\title{
BORÇALI VE ÇILDIR KARAPAPAK / TEREKEME AĞZI SÖZ VARLIĞININ ALINTI SÖZCÜKLER AÇISINDAN KARŞILAŞTIRILMASI ${ }^{*}$
}

\section{Bahadır GÜNEŞ**}

Öz

Bu çalışmada Borçalı ve Çıldır Karapapak / Terekeme ağzındaki alıntı sözcükler, ilgili yörelerden tarafımızca ses kayıt cihazı yardımıyla ve not alarak derlenen metinlerden hareketle karşılaştırmalı olarak gösterilecektir. Bunun yapılmasındaki en önemli neden, söz konusu çalışmanın eş zamanlı ve karşılaştırmalı olmasıdır. $\mathrm{Bu}$ nedenle aynı zaman diliminde derlenen metinlerden yararlanılmıştır. Bir başka deyişle ilgili yörelerden daha önce derlenen metinlerin söz varlığına burada yer verilmemiştir. Bu çalışma, anılan yörelerin söz varlığını bütünüyle ortaya koyma iddiası taşımamaktadır. Aynı kökene sahip Türklerin farklı coğrafya, kültür, siyasi ve sosyal alanlarda varlık gösteren ağızlarındaki söz varlığının eș zamanlı ve karşılaştırmalı olarak nasıl bir sonuç vereceğine dair bir ipucu elde etme düşüncesi hâkimdir.

Anahtar Sözcükler: Karapapak / Terekeme, ağız, söz varlığg, karşılaştırma, alıntı sözcük.

\section{THE COMPARISON OF QUOTED WORDS IN BORÇALI AND ÇILDIR KARAPAPAK / TEREKEME DIALECT}

\begin{abstract}
In this study Borçalı and Çıldır Karapapak / Terekeme quoted words will be shown in comparison related places by us with the help of voice recorder and taking notes compiled text of the support. The study simultaneously and is comparatively the most important reason for this. Therefore, it is used also compiled texts. That does not existence of an earlier text. This study does not specify all of the vocabulary of the places. Karapapak / Terekeme Turkish different geographies, cultures, simultaneously indicating the presence of vocabulary in the dialect in political and social fields and the idea that how to get a result as compared.
\end{abstract}

Keywords: Karapapak / Terekeme, dialect, vocabulary, comparison, quoted word.

\section{Giriş}

Karapapak / Terekeme Türklerinin büyük bölümü bugün Türkiye ve Gürcistan sınırları içinde yaşamaktadır. Türkiye'deki Karapapak / Terekeme Türklerinin ağırlıklı olarak yerleştiği bölge, Ardahan'ın Çıldır ilçesine bağlı köylerdir. Gürcistan'da ise “ata dede Türk yurdu Borçalı" (Alyılmaz, 2003: 15) bu anlamda ilk akla gelen yerdir.

\footnotetext{
* Bu çalışma 8584 numaralı Borçalı (Gürcistan) ve Ardahan / Çıldır Karapapak / Terekeme A ğzının Mukayeseli Incelenmesi başlıklı BAP1 projesi kapsamında Karadeniz Teknik Üniversitesi Bilimsel Araştırma Projeleri tarafindan desteklenmiştir.

** Yrd. Doç. Dr.; Karadeniz Teknik Üni. Edebiyat Fakültesi, Türk Dili ve Edebiyatı Bölümü, bahadir.gunes@hotmail.com.
} 
Özellikle 1828 Türkmençay Antlaşması ve 1877-1878 Osmanl1-Rus savaşı sonucu Türkiye'ye göç etmek zorunda kalan Karapapak / Terekeme Türklerinin büyük bölümü Türkiye'de Kars, Ardahan, Ağrı, Muş, Amasya, Tokat, Sivas illerinin çeşitli yerleşim birimlerinde bulunmaktadır (Bala, 1977: 330; Alyılmaz, 2002: 291; Ercilasun, 2002: 45-46; Aly1lmaz, 2003: 5-6).

Borçalı Karapapak / Terekeme ağzı Azerbaycan Türkçesinin Batı grubu ağızları içinde değerlendirilmektedir. Batı grubu ağızları Borçalı'dan başka Karabağ, Kazak, Gence, Ayrım ağızlarını da kapsamaktadır ${ }^{1}$ (Şireliyev, 1962: 16-17).

Çı1dır Karapapak / Terekeme ağzı ise Türkiye Türkçesi ağızları içinde Doğu grubu ağızlarına dâhil edilmektedir. Karahan'ın (1996: 96) tasnifinde Doğu grubuna bağlı ikinci alt grubun yedinci alt başlı̆̆ altında "Kars Azerileri ve Terekemeleri ağzı" içinde değerlendirilmiştir.

Azerbaycan Türkçesi ağızlarının Batı grubu içinde yer alan Borçalı Karapapak / Terekeme ağzının, Türkiye Türkçesi ağızları içinde özellikle Kars ve çevre ağızları arasında bağlantı görevi üstlendiğini söylemek mümkündür. Ağız özellikleri ve kültürel değerler bakımından Borçalı ile Çıldır Karapapak / Terekeme Türkleri arasında çok fark bulunmadığı bazı kaynaklarda (Ercilasun, 2002: 1-2) belirtilmektedir.

Ağız araştırmalarında genellikle ses ve şekil bilgisi üzerinden mukayese yoluna gidilmekle birlikte, söz varlığı açısından ağızların karşılaştırıldığı çalışmalar da mevcuttur. Bu tür çalışmalarda Türkçenin farklı lehçelerine ait ağızlardaki söz varlığı, hem kendi aralarında hem de diğer Türk lehçeleriyle karşılaştırılmıştır².

\section{Söz Varlığı ve Alıntı Sözcükler}

Bir dilin anlatım olanaklarının temel taşları sözcüklerdir. İletişimde bu temel taşların kavramsal boyutu iletilerin yerine ulaşmasını sağlayan ögelerdir. Ana ve yan olarak temelde iki kola ayrılabilecek olan bu unsurlar, ait oldukları dilin söz varlığını meydana getirir. Söz varlı̆̆ı, bir dilin bütün sözcükleri; bir kişinin veya bir topluluğun söz dağarcığında yer alan sözcükler toplamıdır ${ }^{3}$ (Korkmaz, 2007: 144). Ancak söz varlığı denince yalnızca o dilin sözcükleri değil, deyimlerin, kalıplaşmış sözcüklerin, atasözlerinin, terimlerin ve çeşitli anlatım kalıplarının oluşturduğu bütün de anlaşılır. Ayrıca bu, sadece bir dilde birtakım seslerin bir araya gelmesiyle

\footnotetext{
${ }^{1}$ Karapapak / Terekeme Türklerinin tarihî serüveni ve ağız özellikleri hakkında ayrıntılı bilgi için ayrıca bk. (Alyılmaz, 2003; Güneş, 2013).

${ }^{2}$ Türkçenin iki lehçesinin (Türkiye Türkçesi-Kırgız Türkçesi) söz varlığı açısından kendi aralarında ve diğer Türk lehçeleriyle mukayese edildiği bir çalışma için $b k$. (Alimova, 2011).

${ }_{3}^{3}$ Korkmaz, bu terimi kelime hazinesi șeklinde ele almış ve İngilizcenin kelime hazinesi, üniversite ögrencilerinin kelime hazinesi gibi örneklerle açıklamıştır.
} 
kurulmuş simgeler, göstergeler olarak değil, aynı zamanda o dili konuşan toplumun kavramlar dünyası, maddi ve manevi kültürünün yansıtıcısı, dünya görüşünün bir kesitidir ${ }^{4}$.

Bir dilin söz varlığı, o dilin tarihine geniş ölçüde 1şık tutmakta, asırlar boyunca ortaya çıkan ses, biçim, söz dizimi ve anlam değişikliklerini yansıtmakta ve hangi dillerin etkisiyle ne tür değişimler geçirdiğini göstermektedir. Bu manada Türkçenin tarihî ve modern alanlardaki dil incelemelerinde söz varlığı üzerinde yapılacak çalışmalar büyük bir öneme sahiptir.

Karahan (2008: 51), söz varlığı incelemesiyle bir toplumun yaşam biçimi, gelenek ve görenekleri, siyasi ve sosyal tarihi, çevre kültürlerle olan ilişkileri, toplumsal ve kültürel eğilimlerinin ortaya çıkacağını, belirli bir dönemin sosyal ve kültürel yapısını anlamak, sözcük yapımındaki yeni veya farklı şekilleri tespit etmek ve anlam olaylarını görebilmek için de sözcüklerin birer ipucu olduğunu belirtmiştir.

Bir dilin söz varlığını yalnız kendi kaynaklarından çıkan sözcükler oluşturmaz. Dilin konuşucusu olan milletin tarih içindeki serüvenine bağlı olarak çeşitli sebeplerle etkileşime geçtiği başka milletlerin dilleriyle alışveriş yaparak bu dillerden sözcük alıp kendi dilinden de bu dillere sözcük vermeleriyle oluşan dilsel alışveriş de söz varlığı açısından önemli bir gerçektir.

Bir dili şekillendiren unsurlar, bir bakıma o dili kullanan toplumun sosyal ve kültürel yapısı ve yaşam biçimiyle ilgilidir. Dilin söz hazinesi de toplumun genel yapısını ve ihtiyaçlarını belirleyen kavramlarla oluşmaktadır. Bu bakımdan yeni ihtiyaçlar yeni kavramları, yeni kavramlar yeni kelime ve şekilleri doğurur (Korkmaz, 2005: 948). Bu durum, dilin yeni kavramları karşılamak üzere duyduğu ihtiyacı karşılama yoluna gitmesine neden olur. Bu aşamada dil, kültürel ilişkilerden hareketle söz konusu ihtiyacın bir bölümünü karşılamak üzere alıntı sözcüklerden yararlanır.

Alıntı sözcüklerin dile girişi, milletlerin kültürel ilişkisine bağlı olarak gerçekleşebildiği gibi, devrin getirdiği siyasi, sosyal ve teknolojik gelişmeler ile eğitim yoluyla da bu durum oluşur. Türkçenin sadeleşmeye yönelik adımlar attığı yıllarda Arapça ve Farsça sözcüklerin yerine Türk dilinin kendi kaynaklarından yararlanması yoluna gidilirken Batı kökenli sözcüklerin dil içinde hızlı bir şekilde yayılmasının önüne geçilememiştir. Bunda belirtilen hususlardan biri olarak eğitim için Batı ülkelerine giden araştırmacıların döndüklerinde Batı

\footnotetext{
${ }^{4}$ Aksan $(2006: 7,26)$, bir dilin söz varlığı incelenirken öncelikle "temel söz varlığı" adı verilen organ adları, akrabalık adları, sayılar, insanın maddi ve manevi kültür dairesi içine giren çeşitli kavramların dikkate alınması gerektiğini belirtir.
} 
kökenli sözcükleri çalıştıkları alanlarda fazlaca kullanmalarının etkisinden söz edilir (Aksoy, 1974: 541).

Dil bilimsel alışverişler, karşılıklı kültürel nüfuzların tabiatını ve ehemmiyetini oldukça geniş bir şekilde tayin etme imkânını veren son derece elverişli belirleyicilerdir (Gemalmaz, 2010: 521). Türkçenin dil ilişkilerine bakıldığında tarihin değişik dönemlerinde siyasi, sosyal ve kültürel olaylara bağlı olarak farklı milletlerin dillerinden sözcük alıp bu dillere kendi sözcüklerini verdiği görülür ${ }^{5}$. Tanzimat döneminde yönünü Batı'ya çeviren Osmanlı toplumu özellikle Fransız kültürünün etkisinde kalmış, buradan alınan yeni düşünce ve akımların sosyal yapıya aktarılabilmesi için dilde sade bir anlatım yolunu seçmiştir (Korkmaz, 2005: 952-953). Dolayısıyla kültürel ve düşünsel alanda gerçekleşen ilişkiler, dili de etkilemekte, dilin hem kendi içinde birtakım düzenlemelere gitmesine hem de ilişki içinde olduğu dillerden ilgili kavramlarla birlikte birtakım sözcüklerin alınmasına neden olmaktadır.

Aksan (2006: 29), bir dilden alıntılanan sözcükleri iki biçimde değerlendirmiştir. Bunlardan birincisi, dilin ses eğilim ve kurallarına uymuş, yabancıllı̆̆ belli olmayan "yerleşmiş yabancı sözcükler"; ikincisi ise dilin ses eğilim kurallarına uymayan, yabancılığını belli eden “yerleşmemiş yabancı sözcükler”dir. Karaağaç (1997: 499-501), kişi ve toplulukların diğer kişi ve topluluk dillerinden kendi dillerine sözcük almalarının "öğrenme" ve "özenti” gibi iki ana sebebinin olduğunu, söz konusu alıntıların kaynağının da "iç alıntılar", ve "dış alıntılar", olmak üzere ikiye ayrıldığını belirtmiştir.

Alıntı sözcükler, dilin söz hazinesini ve kavram alanlarını genişletmekle birlikte, dilde var olan birtakım sözcüklerin yerlerini almaları nedeniyle giriş yaptığı dile bu manada katkı sağlamamaktadır. Ayrıca alıntı sözcüklerin kendi ses özellikleri ile başka bir dile girmeleriyle birlikte, bu durum, alıcı dilin genel yapısına uygun olmadığı anda ilgili dilin kavram zenginliği açısından duraksamasına neden olmaktadır (Korkmaz, 2005: 957). Bu manada dilde karşılığ1 olmayan sözcüklerin alınmasına öncelik verilmeli, alıntılanan sözcük dilin kendi yapısına uygun hâle getirilerek kullanılmalıdır. (Korkmaz, 2007: 495). Türkler, genellikle dil ve filoloji hareketlerinde yalnız kendi millî dillerini terbiye etmekle kalmamış, edindikleri yabancı dil sözcüklerini de sıkı sıkıya kendi gramerlerine uydurmakta büyük başarı göstermişlerdir (Caferoğlu, 1969: 26). Bu sağlanmadığı takdirde, toplumsal iletişimde bozulmalar meydana gelecek, bu da millet olma bilincinin zayıflamasına, toplumun geçmişten getirdiği ortak değer yargılarıyla bağlantılarının kesilmesine neden olacaktır.

\footnotetext{
5 Türkçenin komşu dillere verdiği sözcüklere örnek olmak üzere geniş bilgi için bk. (Karaağaç, 1998a: 361-387; Karaağaç, 1998b: 476-495; Karaağaç, 2008).

6 "Kişi, sosyal grup ve şivelerden yapılan alıntılar” (Karaağaç, 1997: 501).

7 "Komşu kavimlerin dillerinden yapılan alıntılar” (Karaağaç, 1997: 501). 
Bilinçli olarak sözcük alıntılaması yapılmadığı zaman, söz konusu yabancı sözcüklerin dile girişi hızlanarak normal bir dil alışverişi sınırını aşmakta, bu da dilde yozlaşmaya neden olmaktadır (Zülfikar, 1996: 5; Karaağaç, 1997: 502; Zülfikar, 1997: 401). Türkçenin çeşitli devrelerde karşılaştığı benzer durumlar, kültürün gerçek sahibi olan halkın karşı koymasıyla dengelenmiştir (Ercilasun, 1995: 1072-1075; Gemalmaz, 2010: 38-40).

\subsection{Borçalı ve Çıldır Karapapak / Terekeme Ağzında Alıntı Sözcükler}

Ağızlar dilin söz varlığına dair zenginliğini bünyelerinde taşıyan en önemli kaynak durumundadırlar. Barındırdıkları sözcüklerin hem standart dilin verileri hem de arkaik özellikli olması, ağızların söz varlığı açısından önemini ortaya koymaktadır. Ayrıca siyasi, sosyal ve kültürel nedenlerle dil üzerinden yapılan alışverişlerle alıntı sözcüklerin dile girmesi, ağızları da etkilemekte, böylece söz konusu alıntıları kendi seslendirme biçimleriyle sunan ağız konuşucuları, bu sözcüklere olduğundan farklı anlamlar da verebilmektedirler.

Borçalı ve Çıldır Karapapak / Terekeme ağzı, konuşurlarının Müslüman olması dolayısıyla Arapça ve Farsça; uzun yıllar Rus yönetiminde yaşamaları nedeniyle Rusça; Borçalı -genellikle Rusça üzerinden olmak üzere- ve Çıldır Karapapak / Terekeme ağzının eğitim ile televizyon, internet gibi yazılı ve görsel yayınların etkisiyle Batı kökenli sözcükleri ve her ağızda olduğu gibi dilin eski dönemlerinden kalma bakiyeleri barındırmaları nedeniyle zengin bir söz varlığına sahiptir.

Alıntı sözcükler, bulundukları dil içinde misafir konumundan çıkıp yapı ve anlam açısından gösterdikleri değişme ve gelişmelerle o dilin malı olabilmektedirler. $\mathrm{Bu}$ manada Borçalı ve Çıldır'daki Karapapak / Terekeme Türklerinin ağzına yerleşen alıntı sözcüklerin, aynı Türk boyunun iki farklı coğrafyada konuşulan ağzında ses ve anlam itibarıyla ne gibi özellikler gösterdiğini az da olsa ortaya koymak bu çalışmanın ana eksenini oluşturmuştur.

Burada yer verilecek sözcükler, birer sözlük malzemesi olabileceklerden seçilmiştir. Bir başka deyişle yöresel söyleyiş özelliği nedeniyle ölçünlü dilden ayrılan her sözcüğe yer verilmemiştir. Bu tür sözcüklerden ancak anlamı bilinemeyecek derecede değişik seslendirilen ve ölçünlü dilden farklı anlamlar içerenler alınmıştır.

Demir (2013: 86-87), standart varyantı olan bir dilin ağızlarının sözlüğü yapılırken ağız ile standart arasına kesin bir çizgi çekilemeyeceğini, ağız sözlüklerinin hazırlanmasında karşılaşılan önemli sorunlardan birinin sözlükbirimlerin seçimi olduğunu belirtmiştir. Demir'e göre, bu aşamada karşılaşılan ilk sorunun, sözlüğe alınacak malzemenin seçiminde hangi ölçütlere başvurulacağı, hangi malzemenin neye göre alınacağıdır. Demir, ağız sözlüklerine alınacak malzemenin seçiminde standart bir yaklaşım olmasa da genel eğilimin, standart dilde 
kullanılan ve yapısında, anlamında veya kullanıldığg bağlamda bir farklılık görülmeyen verilerin sözlüğe alınmaması şeklinde olduğunu belirtmiştir.

Borçalı ve Çıldır Karapapak / Terekeme ağzına dair söz varlığı sunulurken değerlendirmeye alınan madde başı sözcükler ilgili yörelerdeki seslendiriliş biçimleriyle gösterilmiştir. Madde başı sözcüklerin sıklıkla kullanılan farklı söyleniş biçimleri ise ilgili sözcükten ayrı değil, “/” işareti konularak yanında gösterilmiştir. Demir (2013: 90), yerel varyantlar tek biçimli olmadığından bir sözcügün aynı metinde sesçe farklı yapılara dönüşebildiğini, bu tür verilerin ayrı madde başlarında gösteriminin ve birbirine gönderme yapılmasının pratikte çalışmaya sınırlı bir katkı sağladığını belirtmiştir. Bunun yanında değerlendirmeye alınan madde başı sözcüklerin gösteriminde isimler yalın hâlde; fiiller ise mastar biçimleriyle belirtilmiştir.

Borçalı ve Çıldır Karapapak / Terekeme ağzının söz varlığı mukayeseli bir şekilde belirtilirken alıntı sözcüklerin hangi dilden alındığg ve bu dildeki biçimi, ilgili sözcüğün yanında gösterilmiştir. Demir (2013: 91), alıntı sözcüklerin ait oldukları dilin gösterilmesinin kişisel bir tercih olduğunu, köken gösterimiyle ilgili en önemli yöntem sorununun ağızdaki bir sözcüğün doğrudan kaynak dilden mi alındığı yoksa başka dillerden mi kopyalandığının genellikle bilinmemesi olduğunu belirtmiştir. İlgili yörelerde alıntı sözcüklerin kaynak dildeki anlamlarının kullanılması yanı sıra bu sözcüklere zaman zaman yeni anlamlar da kazandırıldığı görülmektedir. Bu çalışmada Borçalı'da tespit edilen alıntı sözcüklerden Batı kaynaklı olanlar büyük oranda Rusçadan kopyalanmıştır. Bu özellikteki Batı kökenli madde baş1 sözcüklerin yanında, tespit edebildiğimiz ölçüde Rusçadaki biçimleri de gösterilmiştir.

Karşılaştırmalı olarak sıralanan madde başları, ilgili yörelerdeki seslendirilme biçimlerine göre alfabetik olarak sıralanmıştır. Mesela; normalde "ḳ" ile seslendirilen bir sözcük tonlulaşma sonucu "g' " ile söyleniyorsa söz konusu sözcüğe "g" maddesi içinde yer verilmiştir. Ayrıca söz konusu madde başı sözcüklerin karşılıkları verilirken genellikle ilgili sözcüğün ölçünlü dildeki karşıllğı; açıklama isteyen sözcüklerde ise anılan yörelerde kullanılan anlamı belirtilmiştir.

Borçalı ve Çıldır Karapapak / Terekeme ağzında alıntı sözcüklerin oranı azımsanmayacak derecededir. Bu sözcüklerden önemli bir bölümü İslam dininin etkisi ve buna bağlı olarak yaşanan siyasi, sosyal ve kültürel değişmelere bağlı olarak Arapça ve Farsça kökenlidir. Bunun yanında özellikle teknolojik gelişme ve değişmelerin etkisiyle yazılı ve görsel yayınlara dayalı Batı kökenli sözcükler de anılan yörelerde belirgindir. Büyük oranda Borçalı'da olmak üzere Rusya'nın uzun süren hâkimiyeti nedeniyle Rusça sözcükler de önemli 
bir orana sahiptir. İlgili yörelerde nadiren görülen alıntılar da "diğer alıntı sözcükler" başlığı altında ele alınmıştır.

\subsubsection{Arapça Kökenli Söz Varlığı}

Borçalı ve Çıldır Karapapak / Terekeme ağzıyla ilgili söz varlığına bakıldığında her iki yörede Arapça kökenli sözcüklerin genellikle aynı şekil ve anlamıyla kullanıldığı görülür. Ancak zaman zaman söyleyiş ve anlamda farklılıklar olabilmektedir. Bu özellikteki madde başı sözcükler, söyleniş ve anlamca aynı olanlar, söylenişleri farklı; anlamları aynı olanlar, Borçalı'da olup Çıldır'da tespit edilemeyenler ve Çıldır'da olup Borçalı'da tespit edilemeyenler şeklinde gösterilmiştir. Değerlendirmeye alınan toplam Arapça kökenli madde başı sözcük say1s1 312'dir.

\subsubsection{Söylenişi ve Anlamı Aynı Olan Arapça Sözcükler}

Borçalı ve Çıldır Karapapak / Terekeme ağzında tespit edilen Arapça kökenli sözcüklerden her iki yöre için de söyleniş ve anlam bakımından ortaklık gösteren madde baş1 sözcük sayısı 108'dir:

Tablo 1: Söylenişi ve Anlamı Aynı Olan Arapça Sözcükler

\begin{tabular}{|c|c|}
\hline Madde Başı & Anlam \\
\hline ahır (âhir) & son, velhas1l, k1saca \\
\hline alosman ('âl-i 'osmân) & Osmanlı Devleti \\
\hline $\operatorname{ar}(' \hat{a} r)$ & utanma \\
\hline $\operatorname{arah}($ 'arak) & ispirtolu içki, rak1 \\
\hline arzıhal / arzuhal ('arz-ı hâl) & dilek, istek \\
\hline áhāta / ehata (ihâta) & kuşatma, etrafını çevirme \\
\hline$a y l f(' a y b)$ & ayıp, utanılacak davranış veya hareket \\
\hline bafat (vefât) & vefat, ölüm \\
\hline bedir (bedr) & dolunay \\
\hline beyyad (b̂̀'at) & bağl1lık; kabul, onay \\
\hline camal (cemâl) & yüz güzelliği \\
\hline cavaf (cevâb) & cevap, yanıt \\
\hline cenup (cenûb) & güney \\
\hline davam (devâm) & devam; devam etme \\
\hline davat (da'vet) & yemekli toplantı, ziyafet \\
\hline dayımı (dâ'imî) & daimi, sonsuz \\
\hline dinar (dînâr) & para birimi \\
\hline edet (âdet) & âdet, usul \\
\hline ègide ('akî̀de) & iman, inanç \\
\hline ehvalat (ahvâl) & hâller, durumlar \\
\hline elèh ('aleyh) & karşı1, karşı1t \\
\hline elem ('âlem) & millet, halk, ahali \\
\hline èlim ('ilm) & ilim \\
\hline ember ('anber) & güzel koku \\
\hline encem / encemi ( encâm) & son, akıbet \\
\hline erz ('arz) & zaman, süre \\
\hline esger ('asker) & asker, nefer \\
\hline$\dot{e} s ̧ \dot{g}$ ('aşk) & aşk, sevgi \\
\hline faylz (fâ'iz) & faiz, oran \\
\hline ferh / ferk (fark) & fark, ayrılık, başkalık \\
\hline
\end{tabular}




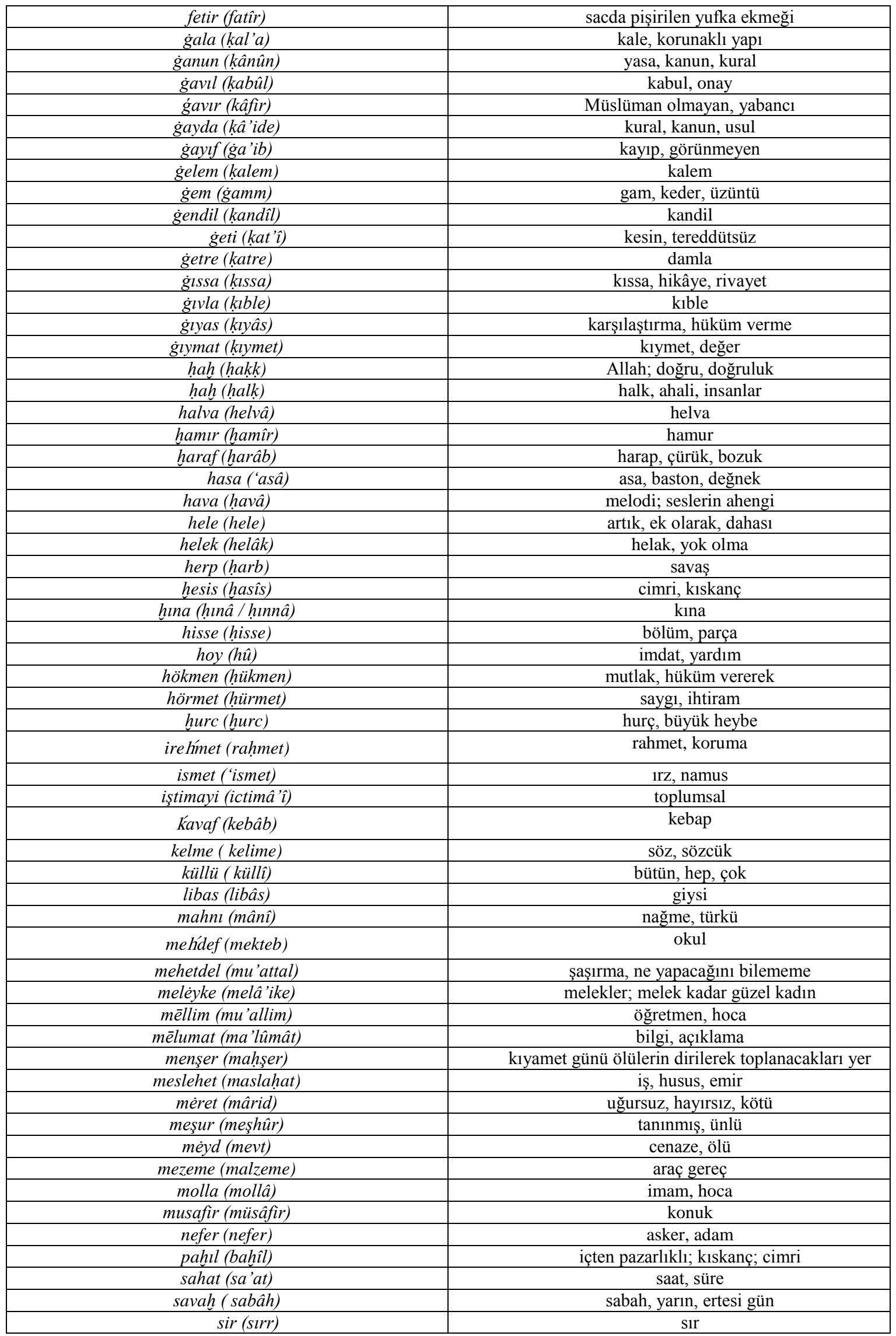




\begin{tabular}{|c|c|}
\hline söhbet (sohbet) & sohbet, karşılıklı konuşma \\
\hline sünnü (sünnî) & Sünni \\
\hline süküt (sükût) & sessiz, sakin; efendi \\
\hline tayfa (tâ'ife) & kavim; halk \\
\hline tecnis (tecnîs) & bir şiir türü \\
\hline telefüz (telaffuz) & söyleyiş, seslendirme \\
\hline telis (tillî̀s) & çuval \\
\hline temiz (temyîz) & temiz; saf, katışıksız \\
\hline tendir (tennûr) & tandir \\
\hline teref (taraf) & yön, yan \\
\hline terviye (terbiye) & edep; eğitim; davranış kuralları \\
\hline tesevür (tasavvur) & zihinde şekillendirme, kurma \\
\hline vaylz (vâ'iz) & kötü, kötü niyetli \\
\hline vede (va'de) & zaman, süre \\
\hline yésir (esîr) & esir, köle \\
\hline$z a d(z \hat{a d})$ & şey, filan \\
\hline zaral (zarar) & kayıp, ziyan \\
\hline zemheri / zehmeri (zemherîr) & kara k1ş \\
\hline ziya (ziyâ) & aydınlık, 1şık, nur \\
\hline
\end{tabular}

Tablo 1 göz önüne alındığında önemli bir bölümü dinî inanışa ait olmak üzere, birbirinden farklı konulara ait Arapça kökenli söz varlığının kullanımında biçim ve anlam açısından Borçalı ve Çıldır yörelerinin büyük oranda örtüştügü görülür.

\subsection{Söylenişleri Farklı; Anlamları Aynı Olan Arapça Sözcükler}

Anılan yöre ağızlarında söylenişleri farklı; anlamları aynı olan Arapça kökenli madde başı sözcüklerin sayısı 60'tır:

Tablo 2: Söylenişleri Farklı; Anlamları Aynı Olan Arapça Sözcükler

\begin{tabular}{|c|c|c|}
\hline \multicolumn{2}{|c|}{ Madde Başı } & \multirow{2}{*}{$\begin{array}{c}\text { Anlam } \\
\text { ('arak) rak1, ispirtolu içki }\end{array}$} \\
\hline Borçalı & Çıldır & \\
\hline arah & $i r a h l$ & \\
\hline $\begin{array}{l}\text { badrican / } \\
\text { badrijen }\end{array}$ & patlican & (bâdincân) patlıcan \\
\hline bäläd & belend & (beled) vâk1f, yetkin \\
\hline bulğuh & buluğ & (bülùg) ergenlik çağ 1 \\
\hline cemahat & camaat & (cemâ'at) topluluk \\
\hline $\begin{array}{l}\text { camuş / comuş / } \\
\text { coñuş }\end{array}$ & camış & (câmûs) camız, manda \\
\hline$d \bar{e} \dot{g} a$ & dakiga & (dakîka) dakika \\
\hline dellal & tellal & (dellâl) tellal, satıcı \\
\hline dövlet & devlet & (devlet) devlet, ülke \\
\hline ecāylf & acaylf & $\left(a c \hat{a}^{\prime} i b\right)$ acayip, tuhaf \\
\hline égyar & ăgyar & (ag்yâr) başkaları \\
\hline èhśan & eysan & (iḩsân) lütuf, iyilik \\
\hline$\dot{e}$ ehtiyat & èhdiyat & (ihtiyât) tedbir; sistem \\
\hline esa & asa & ('asâ) asa, baston \\
\hline eyni & aynı & ('aynî) ayn1, tıpk1, benzer \\
\hline 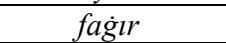 & fă̆lr & (fakîr) yoksul, zavallı \\
\hline fālet & faliyet & (fa'âliyyet) etkinlik, çalışma \\
\hline$\dot{g}$ abir / gebir & $\dot{g}$ evir & (kabr) mezar \\
\hline geden & geder / ğader & (kadar) değin \\
\hline$\dot{g} e l b$ & $\dot{g} e l p$ & (kalb) kalp \\
\hline geyret & $\dot{g}$ gryat & (')ayret) çaba, çalışma \\
\hline hälim & helim & (helîme) içinde yemek pişirilen kaynamış su \\
\hline
\end{tabular}




\begin{tabular}{|c|c|c|}
\hline havar/heber & hever & (haber) haber, bilgi \\
\hline hec & $h a c$ & (hacc) İslam'ın beş şartından biri \\
\hline heigiget & hakget & (hakîkat) gerçek, doğru \\
\hline heseret & eseret & (esâret) tutsaklık \\
\hline hetda & hatda & (hattâ) bundan başka, üstelik \\
\hline heyet & hayat & (hayât) yaşam, yaşam alanı \\
\hline hidmet & hizmet & (hidmet) hizmet, görev \\
\hline himyā & kimya & (kimyâ) kimya \\
\hline ifliç & fels ş & (felc) felç, inme \\
\hline Kalam & kelam & (kelâm) kelam, söz \\
\hline kasad & kesat & (kesâd) az, k1t \\
\hline méçit & mescit & (mescid) mescit, cami \\
\hline mefTun & mefdun & (meftûn) tutkun, vurgun \\
\hline $\begin{array}{l}\text { mellim / melim / } \\
\text { méllim }\end{array}$ & mehellim & (mu’allim) öğretmen, hoca \\
\hline merifat & merfet & (ma'rifet) beceri, başarı; terbiye \\
\hline meselen / meselçin & mesele & (meselâ) örneğin, örnek olarak \\
\hline mesref & meserif & ( masraf) gider, harcama \\
\hline möh'́em & mökgem & (muhkem) sağlam \\
\hline mömün & mümin & (mü'min) Allah'a iman eden kimse \\
\hline muharibe & muharebe & (muhârebe) savaş \\
\hline müselman & müsülman & (müslümân) İslam'a inanan kimse \\
\hline ner & nar & (nâr) ateş, kor \\
\hline nifret & nefret & (nefret) iğrenme; kin \\
\hline niǵah & nikah & (nikâh) kanunî evlenme töreni. \\
\hline nitk & nutuh & (nutk) nutuk, konuşma \\
\hline sahya & saha & (sâha) meydan, alan \\
\hline salam & selem & (selâm) selam \\
\hline sinif & sinif & $(\operatorname{sinf})$ sinif, derece \\
\hline süfre & surfa & (sufre) sofra \\
\hline şähed & şèhit & (şehîd) şehit \\
\hline şèyir & şiyir & (şi'r) şiir, manzume \\
\hline tālí & talih & (tâli') talih, şans \\
\hline tedbir & tedvir & (tedbîr) çözüm, önlem \\
\hline tèlim & talim & (ta'lîm) eğitim, öğrenme \\
\hline terïget & tarikat & (tarîkat) tarikat \\
\hline türfe & türve & (türbe) türbe, kabir, mezar \\
\hline zibil & zivil & (zibl) çöp, süprüntü \\
\hline
\end{tabular}

Yap1 ve anlam bakımından Arapça kökenli söz varlığının iki yöredeki kullanımı dikkate alındığında anlam aynılığının devam edip biçim farklılığının ortaya çıktığı sözcüklerin sayısının daha az olduğu ortaya çıkmaktadır. Bu durumun oluşmasında ağızların doğal sınırlarına müdahale olan idari taksimatın etkisinden söz edilebilir.

\subsection{Borçalı'da Olup Çıldır'da Tespit Edilemeyen Arapça Sözcükler}

Borçalı ve Çıldır Karapapak / Terekeme ağzının genel söz varlığı bakımından büyük oranda örtüştüğü aşikârdır. Ancak Türkçe kökenli sözlük malzemesi yanı sıra alıntı sözcüklerde de farklı kullanımlar göze çarpmaktadır. Bu durum, Arapça kökenli madde başı sözcükler için de geçerlidir. Her iki yöreden aynı zaman diliminde tarafımızca derlenen metinlerin içerdiği söz varlığına bakıldığında Arapça kökenli sözlük malzemesi olarak Borçalı yöresinde tespit edilip 
Çıldır Karapapak / Terekeme ağzında tespit edilemeyen Arapça kökenli sözcüklerin sayısı 83’tür:

Tablo 3: Borçalı'da Olup Çıldır'da Tespit Edilemeyen Arapça Sözcükler

\begin{tabular}{|c|c|}
\hline Madde Başı & Anlam \\
\hline$b \bar{a} \dot{g} l(b \hat{a} k \hat{\imath})$ & bölme işleminde kalan sayı \\
\hline beli (belî) & onaylama ifadesi; evet \\
\hline cenub (cenûb) & güney \\
\hline dayı̌mı (da'imî) & sonsuz, ebedi \\
\hline degik (dakik $)$ & dakik; sözünün eri \\
\hline eclaf (eclâf) & mürüvvetsiz, alçak \\
\hline ecvaf (ecvef) & alçak, rezil \\
\hline ehvalat (aḥvâl) & hâller, durumlar \\
\hline ekseren (ekseriyyâ) & çoğunlukla, genellikle \\
\hline ekseret / esseriyat (ekseriyyet) & çoğunluk \\
\hline evez (a'vâz) & karşıll1k, bir şeyin yerini tutan unsur \\
\hline fehr $r(f a h r)$ & gurur, övünme \\
\hline fesil (fasl) & mevsim \\
\hline$\dot{g} e d d e r(\dot{g} a d d \hat{a} r)$ & zalim, acımasiz \\
\hline$\dot{g} e s e b e($ kasaba $)$ & kasaba, ilçe \\
\hline$\dot{g} e z e b(\dot{g} a z a b)$ & öfke, kızgınlık \\
\hline halhazar (hâal-i hâazır) & şimdiki durum \\
\hline havas (havâss) & saygin olanlar \\
\hline heǵgí (hakîkî̀) & gerçek \\
\hline heg $\dot{g}_{\dot{g} e t e n}$ (hakikikaten) & gerçekten \\
\hline ihdisas (ihtisâs) & uzmanlik \\
\hline imériyèt (imâret) & bayındırlık \\
\hline imtiyaz (imtiyâz) & ayricalık \\
\hline ink işaf (inkişâf) & oluşma, ortaya çıkma \\
\hline isTehkkam (istiḥkâm) & asker, kuvvet \\
\hline işTimāyi (ictimâ'̂̀) & toplumsal \\
\hline kelf $($ kelb $)$ & köpek \\
\hline legeb (lâkab) & lakap, takma ad \\
\hline lel (la’l) & değerli bir taş \\
\hline mälice / mualce (mu'âlece) & tedavi; ilaç \\
\hline mégam (makâm) & makam; zaman \\
\hline mehbus (mahbûs) & tutuklu \\
\hline mehebbet (muhabbet) & aşk, sevgi \\
\hline mekalat (makâalât) & sözler, yazılar \\
\hline mēna (ma'nâ) & anlam \\
\hline mēsul (maḥsûl) & ürün \\
\hline mētem (mâtem) & yas \\
\hline möhnet (miḥnet) & acı, üzüntü \\
\hline möhübbēt (muḥabbet) & sevgi \\
\hline
\end{tabular}




\begin{tabular}{|c|c|}
\hline mugiavle (mukâvele) & sözleşme \\
\hline muğenni (muġannî) & şarkı1c1 \\
\hline müeyyen (mu'ayyen) & belirli \\
\hline münbit (münbit) & bereketli \\
\hline müsellim (müsellim) & idari bir unvan \\
\hline nagis (naḳ̂s) & eksi, eksik \\
\hline nayhe (nâhiye) & bölge \\
\hline názer (nazar) & bakış; iltifat \\
\hline nēre (na'ra) & bağırma, yüksek ses \\
\hline nesiyet (nasîhat) & öğüt \\
\hline nezire (nazîre) & benzetme; şiir \\
\hline$s a ́ d r(s a d r)$ & başkan \\
\hline sáḥra (saḥrâ) & çöl, ova \\
\hline $\operatorname{seyf}(\operatorname{seh} v)$ & yanlış, yanılma \\
\hline seyyad (sayyâd) & avc1 \\
\hline $\sin (\sin n)$ & yaş, ömür \\
\hline sünü (sun'î) & yapay \\
\hline süPha (subh) & sabah \\
\hline şerayit (şerâ'it) & şartlar, gerekli unsurlar \\
\hline şerk (şark) & $\operatorname{doğ} u$ \\
\hline şiye (şi’â) & Şii \\
\hline şó (şuâ') & 1 ş1k \\
\hline teǵgaút (tekâ'üd) & emeklilik \\
\hline tēmir (ta'mîr) & onarma \\
\hline tercümeyi hal (tercüme-i hâl) & özgeçmiş \\
\hline teserufat (tasarrufât) & geçim, geçinme \\
\hline$\ddot{u} \operatorname{SüF}\left({ }^{\prime} u z v\right)$ & uzuv, organ, parça \\
\hline vāldèyn (vâlideyn) & anne ve baba \\
\hline verák (varak) & yaprak, sayfa \\
\hline$z \bar{a} y i T$ ( zâ'id) & toplama (matematik) \\
\hline
\end{tabular}

Borçalı'da tespit edilen söz konusu madde başı sözcüklere Çıldır Karapapak / Terekeme ağzında rastlanmaması, kesinlik bildirmemekte, büyük oranda çalışmanın sınırlandırılmasına bağlı bir durum olarak ortaya çıkmaktadır. Bir başka deyişle Çıldır Karapapak / Terekeme ağzıyla ilgili yapılacak daha ayrıntılı bir söz varlığı çalışmasıyla Borçalı'da tespit edilen sözcüklerin kullanımına rastlanabilir.

\subsubsection{4. Çıldır'da Olup Borçalı'da Tespit Edilemeyen Arapça Sözcükler}

Mevcut metinler üzerinde yapılan taramalar sonucu Çıldır Karapapak / Terekeme ağzında tespit edilen; ancak aynı dönemde derlenen Borçalı Karapapak / Terekeme ağzında rastlanmayan Arapça kökenli sözcüklerle de doğal olarak karşılaşılmıştır. Söz konusu bağlamda ele alınabilecek Arapça kökenli madde başı sözcük sayısı 61'dir:

Tablo 4: Çıldır'da Olup Borçalı'da Tespit Edilemeyen Arapça Sözcükler

\begin{tabular}{|c|c|}
\hline Madde Başı & Anlam \\
\hline al (âl) & hile, tuzak \\
\hline alaf(alef) & hayvan yemlerinin genel adi \\
\hline ale ('alâ) & yüce \\
\hline beret (berât) & ferman \\
\hline cerìya (câriye) & hizmetçi \\
\hline divan / divan (dîvân) & büyük meclis; bir şiir türü \\
\hline düvel (düvel) & devletler \\
\hline
\end{tabular}




\begin{tabular}{|c|c|}
\hline$e d a(e d \hat{a})$ & tavır, davranış \\
\hline éğdam (i'dâm) & idam \\
\hline ekseri (ekserî) & çoğunluk \\
\hline eriz ('ârıza) & eziyet \\
\hline faya (fâyihâ) & güzel kokulu nesne \\
\hline fenā (fenâ) & fani olma \\
\hline firğat (firkat) & ayrilık \\
\hline fuǵara / fuğara (fukarâ) & fakir \\
\hline$\dot{g} a d($ kadd $)$ & boy, endam \\
\hline gerál (karâr) & karar \\
\hline hamayıl (hamâ'il) & muska \\
\hline hançal (hancer) & hançer \\
\hline hesir (hasîr) & kalın otlarla örülmüş yer yaygısı \\
\hline hikeyet (hikâyet) & yaşanmış olay \\
\hline$h \operatorname{in}(h \hat{\imath} n)$ & zaman, devir \\
\hline hurcun (hurc) & heybe, torba \\
\hline hö̈düt (ḥudûd) & sinır \\
\hline lsdırāt (istirâhat) & dinlenme \\
\hline ifdahar ( iftihâr) & övünme \\
\hline ilmi nizam ('ilm-i nizâm) & düzen \\
\hline kaza $($ kazâa & ilçe \\
\hline kehlen (küheylân) & soylu at \\
\hline mabal (vebâl) & günah \\
\hline mahtab (muḥâtab) & hitap edilen, dikkate alınan \\
\hline mal (mâl) & büyükbaş hayvan \\
\hline mamfāt (menfa'at) & çıkar, fayda \\
\hline matrah (mitrak) & bir tür kamçı \\
\hline mensil (mahsûl) & yağ, peynir vb. hayvansal ürünler \\
\hline misgi ember (misk ü 'anber) & çok güzel koku \\
\hline muǵadderet (mukadderât) & alın yazıs1 \\
\hline muhbür (muhbir) & haber getirip götüren \\
\hline mutasarrif ( mutasarrif) & idare amiri, vali \\
\hline müsdeşāar (müsteş’ar) & müsteşar; bilgili kişi \\
\hline mütalá (mütâla'a) & okuma, inceleme \\
\hline müzevir (müzevvir) & dedikoducu \\
\hline nă̆gl (nakl) & şiir; öykü, masal anlatma \\
\hline palha ( bakla) & bakla, bezelye \\
\hline $\operatorname{sahan}(\operatorname{sahn})$ & derinliği az, küçük kap \\
\hline sahav / sayaf (sâhib) & sahip \\
\hline seyef (sebeb) & sebep, neden \\
\hline sèyran (seyrân) & gezi, piknik \\
\hline sifir (sıfr) & boş; önemsiz; kolay \\
\hline sikge (sikge) & madenî para; uzun demir \\
\hline suval (su'âl) & soru \\
\hline şayir (şấ'ir) & şair \\
\hline şèyih $($ şeyh $)$ & şeyh, mürşit \\
\hline şōle (şu'le) & şule, 1 şık \\
\hline tahdir (takdîr) & değer verme; başarı belgesi \\
\hline tantana $($ tantana $)$ & karış1klık, kargaşa \\
\hline tekmil (tekmîl) & tam, eksiksiz \\
\hline tevellüt (tevellüd) & doğum tarihi \\
\hline tevliget (tebligât) & bildirim \\
\hline ülfet (ülfet) & dostluk, samimiyet \\
\hline zevrah (zevrak) & kayık, sandal \\
\hline
\end{tabular}

Tablo 4'te yer alan Çıldır'da tespit edilip Borçalı'da rastlanmayan Arapça kökenli sözcüklerin durumu da yukarıda belirtildiği üzere çalışmanın sınırlarıyla ilgili bir durumdur. Bir 
önceki tabloda dile getirilen, Borçalı'da yapılacak kapsamlı bir söz varlığı çalışmasıyla ortaya çıkacak verilerin göstereceği özellikler burada da geçerlidir.

\subsubsection{Farsça Kökenli Söz Varlığı}

Borçalı ve Çıldır Karapapak / Terekeme ağzında tespit edilen Farsça kökenli madde baş1 sözcükler, söyleniş ve anlamca aynı olanlar, söylenişleri aynı; anlamları farklı olanlar, söylenişleri farklı; anlamları aynı olanlar, söyleniş ve anlamca farklı olanlar, Borçalı'da olup Çıldır'da tespit edilemeyenler ve Çıldır'da olup Borçalı'da tespit edilemeyenler şeklinde tasnif edilmiştir. Toplamda 126 adet Farsça kökenli madde başı sözcük değerlendirilmiştir.

\subsubsection{Söylenişi ve Anlamı Aynı Olan Farsça Sözcükler}

İlgili ağızlarda görülen Farsça kökenli sözcüklerden söylenişleri ve anlamları aynı olanlar, diğer iki gruba göre daha fazladır. Bu durum, Farsça kökenli söz varlığı açısından da Borçalı ve Çıldır Karapapak / Terekeme ağzının büyük oranda benzerlik gösterdiğini ortaya koymaktadır. Bu özelliklere sahip tespit edilen madde başı sözcük sayısı 44'tür:

Tablo 5: Söylenişi ve Anlamı Aynı Olan Farsça Sözcükler

\begin{tabular}{|c|c|}
\hline Madde Başı & Anlam \\
\hline$a h u(\hat{a h h})$ & ceylan, karaca \\
\hline baravar (berâber) & beraber, birlikte \\
\hline bęçere (bî-çâre) & çaresiz, zavallı \\
\hline bèd (bed) & kötü, çirkin \\
\hline bèl (bel) & toprak işlemede kullanılan kürek \\
\hline benöyşe (benefşe) & menekşe \\
\hline bes (bes) & yeter; tamam \\
\hline da $\breve{g}(d \hat{a} \dot{g})$ & kızgın demirle bedene vurulan nişan; yara \\
\hline $\operatorname{dem}($ dem $)$ & zaman; saat; devir \\
\hline dest (dest) & el \\
\hline dür (dürr) & inci \\
\hline gor $(g \hat{u} r)$ & mezar \\
\hline hal (hâl) & vücuttaki siyah noktalar, ben \\
\hline hefde (hefte) & hafta \\
\hline hemeşe (hemîse) & daima, her zaman \\
\hline$h \dot{e} s ̧(h \hat{\imath} c ̧)$ & hiç \\
\hline hirman ( hirmen) & harman, hasat \\
\hline hünkar ( hünkâr) & padişah, sultan \\
\hline hürü (hûrrî) & cennet k1z1, sevgili \\
\hline kanar (kenâr) & kenar, kıy1 \\
\hline kar (kâr) & kazanç \\
\hline kem (kem) & fena, kötü \\
\hline kor (kûr) & kör, gözleri görmeyen \\
\hline köhne (köhne) & eski, kadim \\
\hline leşger (leşker) & asker, nefer \\
\hline mah (mâh) & ay \\
\hline mèşe (mîşe) & ağaçlık alan, orman \\
\hline müjǵan (müjgân) & kirpik, kirpikler \\
\hline
\end{tabular}




\begin{tabular}{|c|c|}
\hline nöker (n̂िger) ${ }^{8}$ & hizmetçi, erkek hizmetçi \\
\hline para (pâre) & parça, bölüm \\
\hline payız (pâyîz) & sonbahar \\
\hline peder (peder) & baba \\
\hline pèndir ( penîr) & peynir \\
\hline pesşe (pîş̧e) & alışkanlık, huy \\
\hline pul (pûl) & para, akçe \\
\hline şad (şâd) & sevinç, neşe \\
\hline şeher (şehr) & şehir \\
\hline tarmar (târ u mâr) & dağınık, paramparça \\
\hline ter (ter) & taze, yeni \\
\hline$t \dot{e} z(t \hat{z})$ & çabuk, hızlı \\
\hline teze (tâze) & taze, yeni \\
\hline vèran (vîrân) & viran, harabe \\
\hline yad (yâd) & hatır, hatırlama \\
\hline yeren (yârân) & dost, arkadaş \\
\hline
\end{tabular}

İncelemeye konu olan yörelerdeki Arapça kökenli söz varlığında olduğu gibi, Farsçadan alınan sözcüklerde de biçim ve anlam açısından ortak olan madde başı sözcüklerin sayısı, bu kapsamda yer verilen diğer başlıklar altında belirtilen sözcüklerden daha fazladır. Dolayısıyla Farsça kökenli sözcüklerin kullanımında da Borçalı ve Çıldır Karapapak / Terekeme ağzında ortaklık söz konusudur.

\subsubsection{Söylenişleri Farklı; Anlamları Aynı Olan Farsça Sözcükler}

Borçalı ve Çıldır Karapapak / Terekeme ağzındaki Farsça kökenli madde başı sözcüklerin meydana getirdiği söz varlı̆̆ı içinde söylenişleri farklı; anlamları aynı olan sözcüklerin sayısı 23'tür:

Tablo 6: Söylenişleri Farklı; Anlamları Aynı Olan Farsça Sözcükler

\begin{tabular}{|c|c|c|}
\hline \multicolumn{2}{|c|}{ Madde Başı } & \multirow{3}{*}{$\frac{\text { Anlam }}{\text { (âvâre) işsiz, boş }}$} \\
\hline Borçalı & Çıldır & \\
\hline avarā & avara & \\
\hline bava & $b a b a$ & (bâbâ) baba \\
\hline cávan & cavan & (cevân / cüvân) genç \\
\hline dasdan & desden & (destân) destan \\
\hline dene & tene & (dâne) adet, tane \\
\hline divar & duvar / tufar & (dîvâr) duvar, set \\
\hline garpız & garpuz & (hârbüz) karpuz \\
\hline gonçe & gonca & (gonce) gonca \\
\hline gövher & gafar & (gevher) cevher, elmas \\
\hline har & hor & (hâr) hor, hakir, bayağ \\
\hline Kağız & Kağglt & (kâgaz) kâğıt \\
\hline kümbez & kümbet & (kümbed) kümbet, kubbe \\
\hline$m \bar{a} y \dot{e}$ & maya & (mâye) maya, kök, öz \\
\hline mercime & mercimeh' & (merdümek) mercimek \\
\hline nezik & nezih' & (nâzik) ince, narin \\
\hline niǵar & niyar & (nigâr) güzel kadın, kadın adı \\
\hline novruz / nōyruz & noyruz & $(n e v-r \hat{u} z)$ nevruz \\
\hline pulov & piloy / puloy & (pelâv/pilâv) pilav \\
\hline
\end{tabular}

\footnotetext{
${ }^{8}$ Ölmez (2009: 266), bu sözcüğün kökeninin Moğolcaya dayandığını belirtmiştir.
} 


\begin{tabular}{|c|c|c|}
\hline sāye & saya & (sâye) gölge, himaye \\
\hline serkerde & sergender & (ser-kerde) baş, öncü \\
\hline şáhmar & şahmar & (şâh- mâr) y1lan şahı \\
\hline şerin & şirin & (şîrîn) şirin, tatlı \\
\hline temaşa & tamaşa & (temâşấ) seyir, seyretme \\
\hline
\end{tabular}

Farsça kökenli sözcüklerden biçimi farklı, anlamı aynı olanlar, biçim ve anlamca aynı olanlara göre daha az; ancak biçimce aynı; anlamca farklı olanlar ve hem biçim hem de anlamca farklı olanlardan daha çoktur. Bu durum, Farsça kökenli sözcükler açısından iki yörenin büyük oranda örtüştüğü sonucunu doğurmaktadır.

\subsubsection{Söylenişleri Aynı; Anlamları Farklı Olan Farsça Sözcükler}

Farsça kökenli olup söylenişleri aynı; anlamları farklı olan madde başı sözcüklerin oranı, diğer iki grupla karşılaştırıldığında oldukça düşüktür. Mevcut metinlerde tespit edilen bu özelliğe sahip madde başı sözcük sayısı 4’tür:

Tablo 7: Söylenişleri Aynı; Anlamları Farklı Olan Farsça Sözcükler

\begin{tabular}{|c|c|c|}
\hline \multirow{2}{*}{ Madde Başı } & \multicolumn{2}{|c|}{ Anlam } \\
\cline { 2 - 3 } & Borçalı & Çוldır \\
\hline ayna (âyîne) & pencere & ayna \\
\hline desde (deste) & savaş birliği, asker & deste, tutam \\
\hline huruş (hurûs) & pilavla birlikte yenen \\
et, tavuk vb. & coşkunluk; sataşma \\
\hline zil (zil) & eğlence, sefa & zil \\
\hline
\end{tabular}

\subsubsection{Söyleniş ve Anlamca Farklı Olan Farsça Sözcükler}

Borçalı ve Çıldır Karapapak / Terekeme ağzında söyleniş ve anlamca farklı olan Farsça kökenli madde başı sözcük sayısı 2'dir:

Tablo 8: Söyleniş ve Anlamca Farklı Olan Farsça Sözcükler

\begin{tabular}{|c|c|c|c|}
\hline \multicolumn{2}{|c|}{ Madde Başı } & \multicolumn{2}{c|}{ Anlam } \\
\hline Borçalı & Çıldır & Borçalı & Çıldır \\
\hline $\begin{array}{c}\text { serencam (ser- } \\
\text { encâm) }\end{array}$ & serencem & emir & $\begin{array}{c}\text { âşıklık geleneğinde } \\
\text { şiir okuma faslı }\end{array}$ \\
\hline néft (neft) & nöyüt & petrol & gazyağı \\
\hline
\end{tabular}

\subsubsection{Borçalı'da Olup Çıılır'da Tespit Edilemeyen Farsça Sözcükler}

Mevcut veriler üzerinde yapılan taramalar sonucu Borçalı Karapapak / Terekeme ağzında olup Çıldır yöresinde tespit edilemeyen Farsça kökenli madde başı sözcük sayısı 32'dir. Bunlardan sadece 3 tanesi Farsçadaki biçimiyle kullanılmıştır. Geriye kalan 29 sözcük biçim değişikliğine uğramıştır. 
Tablo 9: Borçalı'da Olup Çıldır'da Tespit Edilemeyen Farsça Sözcükler

\begin{tabular}{|c|c|}
\hline Madde Başı & Anlam \\
\hline $\bar{a} s u d a(\hat{a} s \hat{u} d e)$ & rahat, kaygisız \\
\hline banisdan (bân-istân) & koyun, kuzu barınağı \\
\hline bar (bâr) & meyve, mahsul \\
\hline berpay / berp (berpâ) & yıkılmamış, ayakta \\
\hline çeşm_i cadl (çeşm-i câdû) & büyüleyen göz \\
\hline çırahvian (çerấg-bân) & 1ş1kçı, 1şık tutan \\
\hline fehfur (faǵfurr) & eskiden Çin imparatorlarına verilen unvan \\
\hline galtavan (kaltabân) & iri yarı, tipsiz; namussuz \\
\hline har (hâr) & diken \\
\hline hasand (âsân) & kolay \\
\hline hemen / hemin (hemîn) & bir şeyin aynısı, benzeri \\
\hline herÇ merc (herc ü merc) & darmadağın \\
\hline hirdar (hırîdâr) & müşteri; sarraf \\
\hline kan (kân) & kaynak, menba \\
\hline Karvan (kervân) & kervan \\
\hline kes (kes) & kimse \\
\hline kèşmekèş (keşmekeş) & çekişme, mücadele \\
\hline merdene (merd-âne) & mertçe \\
\hline merdi merdene ( merd-i merd-âne) & yiğitler yiğidine yakışacak şekilde \\
\hline neve (neve) & torun \\
\hline pünhan (pinhân) & gizli \\
\hline $\operatorname{sar}($ sâr$)$ & yırtıcı bir kuş türü \\
\hline sergerdān (ser-gerdân) & avare, başıboş \\
\hline sitāy iş (sitâyiş) & ibadet, tapınma \\
\hline şah (şah) & dal, budak \\
\hline şèda (şeydâ) & âş1k, divane \\
\hline $\operatorname{sir}(\hat{i} \hat{\imath} r)$ & aslan \\
\hline tembeke (tenbâku) & tütün, nargile tütünü \\
\hline tite (dide) & göz; göze düşen ak leke \\
\hline zer (zer) & altın \\
\hline zerger (zer-ger) & kuyumcu \\
\hline zindanban (zindân-bân) & zindanc1, hapishane görevlisi \\
\hline
\end{tabular}

Çalışmanın sınırlarına bağlı olarak Borçalı'da tespit edilen; ancak Çıldır'da tespit edilemeyen Farsça kökenli sözcüklerin çokluğu açısından Borçalı'nın öne çıkmasında Borçalı'nın belli bir dönem Fars egemenliği altında yaşamasının etkisinden söz etmek mümkündür.

\subsubsection{6. Çıldır'da Olup Borçalı'da Tespit Edilemeyen Farsça Sözcükler}

Çıldır Karapapak / Terekeme ağzında tespit edilip Borçalı yöresinden aynı dönemlerde derlenen metinlerde tespit edilemeyen Farsça kökenli madde başı sözcük sayısı 21'dir. Bu sözcüklerin yalnız 2 tanesi Farsçadaki biçimiyle kullanılmıştır.

Tablo 10: Çıldır'da Olup Borçalı'da Tespit Edilemeyen Farsça Sözcükler

\begin{tabular}{|c|c|}
\hline Madde Başı & Anlam \\
\hline aşna (âşsinâ) & bildik, tanıdık; sevgili \\
\hline bèh (pey) & $\begin{array}{l}\text { düğün öncesi dünürlerin birbirlerine gönderdikleri } \\
\text { hediyeler }\end{array}$ \\
\hline ßusa (bûse) & öpücük \\
\hline $\operatorname{cazl}(\operatorname{cad} d \hat{u})$ & cad1 \\
\hline
\end{tabular}




\begin{tabular}{|c|c|}
\hline $\operatorname{dest}($ dest $)$ & el \\
\hline gülüşs̄an (gül-şen) & gül bahçesi \\
\hline güman (gümân) & güven; umut \\
\hline hana (hâne) & deyiş; bölüm; ev \\
\hline$h u b(h \hat{u} b)$ & güzel \\
\hline lesşKer (leşker) & asker \\
\hline möhürder (mühr-dâr) & devletin resmî mührünü kullanmaya yetkili kimse \\
\hline pejmürde (pejmürde) & eski, solgun, dağınık \\
\hline pervaz (pervâz) & giysilerin yaka, kol vb. yerlerine dikilen parça \\
\hline pey (pây) & boş alan, yıkılmış yap1 yeri \\
\hline piyalá (piyâle) & kadeh \\
\hline suvarl (süvârî) & atli \\
\hline şahbaz (şâh-bâz) & becerikli; yiğit, mert \\
\hline şikāar (şikâr) & av \\
\hline şille (sîlî) & sille, tokat \\
\hline tat (tât) & Acem, Şii \\
\hline$y \bar{a} d(y \hat{a} d)$ & yabanc1 \\
\hline
\end{tabular}

Yörelerden birinde tespit edilen; fakat diğerinde rastlanmayan sözcüklerin varlı̆̆ yukarıda da belirtildiği üzere genellikle çalışmanın sınırlarına bağlı olarak oluşmaktadır. Dolayısıyla bu konuda kesin bir yargıya varmak güçtür.

\subsubsection{Rusça Kökenli Söz Varlığı}

Başta Borçalı olmak üzere Karapapak / Terekeme Türkleri, belli bir dönem Rus ve dolayısıyla Rusça etkisi altında yaşamışlardır. Söz konusu durum, siyasi ve sosyal etkilerin yanında dil esasında da birtakım alışverişleri beraberinde getirmiştir. Bu manada Borçalı ve Çıldır Karapapak / Terekeme ağzında Rusça söz varlı̆̆ı, özellikle sözcük düzeyinde belirgindir. Ancak mevcut metinlere bakıldığında Borçalı Karapapak / Terekeme ağzında bu durumun daha çok öne çıktığı görülmektedir. Öyle ki saha çalışmaları sırasında yaptığımız gözlemlere göre, bugün Gürcistan'da yaşayan Karapapak / Terekeme Türklerinin ülkedeki Gürcü ve diğer milletlerle arasındaki iletişim dili büyük oranda hâlâ Rusçadır. Dolayısıyla Borçalı ve Çıldır Karapapak / Terekeme ağzındaki Rusça söz varlı̆̆ı, iki yöreyi bu açıdan birebir olarak karşılaştıracak derecede değildir. Bu nedenle aşağıda önce Borçalı, daha sonra da Çıldır'a ait Rusça söz varlığı gösterilmiştir. Bu çalışmada ele alınan Rusça kökenli madde başı sözcüklerin her iki yöredeki toplam sayısı 58'dir:

\subsubsection{Borçalı Karapapak / Terekeme Ağzında Rusça Söz Varlığı}

Borçalı Karapapak / Terekeme ağzında tespit edilen Rusçadan alınan madde baş1 sözcükler, biçim ve anlamca Rusça ile aynı olanlar ve biçimi farklı; anlamı aynı olanlar şeklinde iki alt başlıkta gösterilmiştir.

\subsection{Rusçadaki Biçim ve Anlamıyla Aynı Olan Sözcükler}

Borçalı Karapapak / Terekeme ağzından tarafımızca derlenen metinler üzerinde yapılan incelemelere göre, Rusçadaki biçim ve anlamıyla kullanılan sözcük sayısı 5 'tir: 
Tablo 11: Rusçadaki Biçim ve Anlamıyla Aynı Olan Sözcükler

\begin{tabular}{|c|c|}
\hline Madde Başı & Anlam \\
\hline banka (banka) & kavanoz \\
\hline çar (çar) & kral (unvan) \\
\hline ruçka (ruçka) & kalem \\
\hline tort (tort) & pasta \\
\hline türma (türma) & hapishane \\
\hline
\end{tabular}

\subsection{Biçimi Farklı; Anlamı Aynı Olan Sözcükler}

Borçalı Karapapak / Terekeme ağzında Rusçadan biçimce ayrılan; ancak anlam aynılığını koruyan sözcük sayısı daha çoktur. Yapılan incelemelere göre bu özelliği gösteren Rusça kökenli madde başı söz sayısı 42'dir:

Tablo 12: Biçimi Farklı; Anlamı Aynı Olan Rusça Kökenli Sözcükler

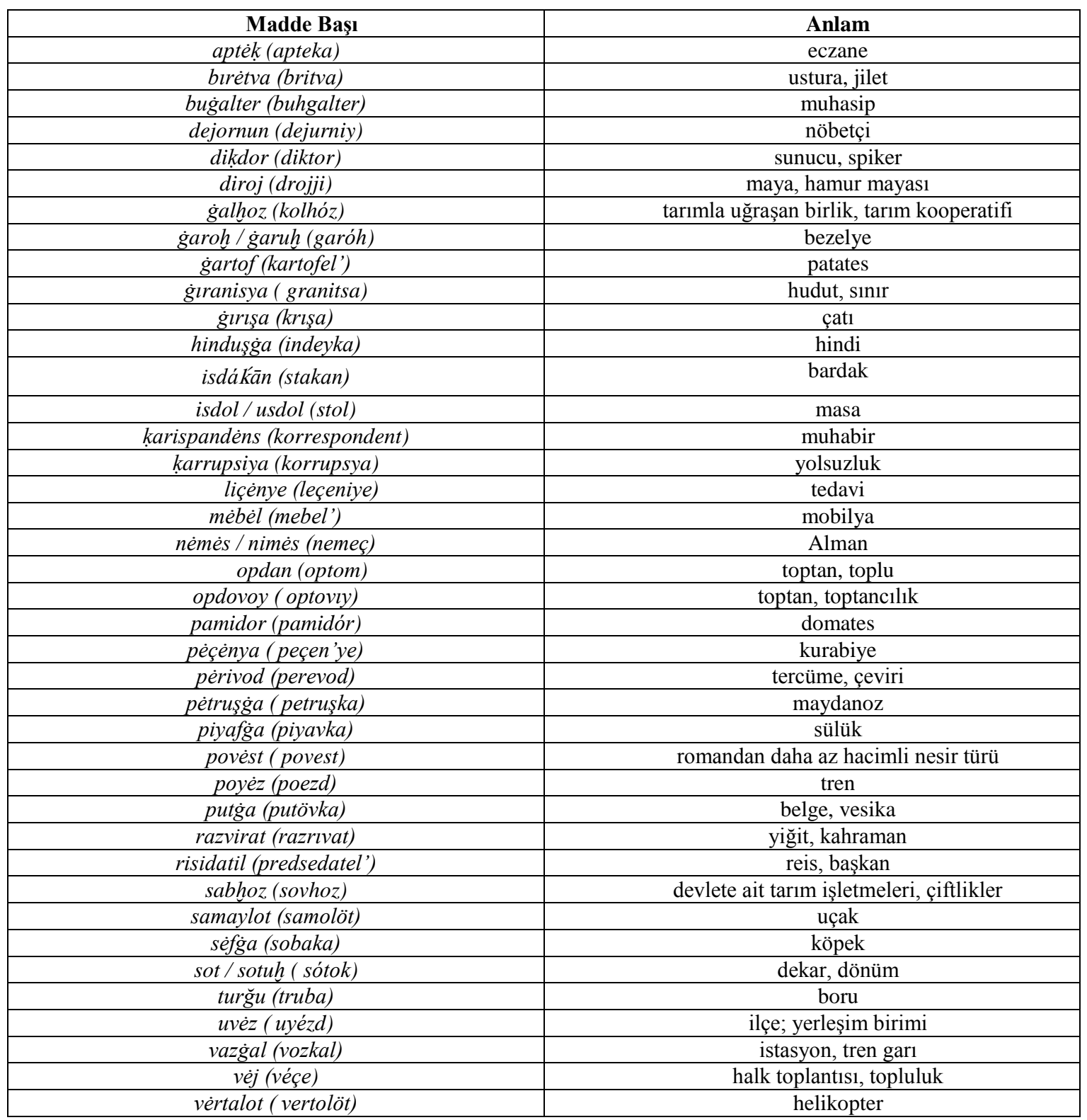




\begin{tabular}{|c|c|}
\hline virahnarot (vrag narod) & halk düşmanı \\
\hline vubérniya (guberniya) & il, vilayet \\
\hline
\end{tabular}

Borçalı Karapapak / Terekeme ağzında tespit edilen Rusça söz varlığının biçimce Rusçadan ayrılanların sayısının birebir aynı olanlardan çok olması, söz konusu madde başı sözcüklerin önemli bir bölümü esasında alıntıların büyük oranda yörenin seslendirme biçimlerine uydurulduğunu gösterir.

\subsubsection{2. Çıldır Karapapak / Terekeme Ağzında Rusça Söz Varlığı}

Borçalı yöresi kadar olmasa da Çıldır da bağlı bulunduğu coğrafi bölgeyle birlikte bir dönem Rus işgali altında yaşamış, birtakım siyasi etkiler yanı sıra sosyal ve kültürel açıdan da Rus etkisini bir şekilde hissetmiştir. Söz konusu tesirin öne çıkardığı önemli bir durum, dil düzeyinde Rusça kökenli söz varlığının Çıldır Karapapak / Terekeme ağzına da sirayet etmesidir. Ancak Rusça kökenli söz varlığının kullanım oranı eskisi kadar yoğun değildir. Tarafımızca bölgeden yapılan derlemelerde sınırlı sayıda örnekle karşılaşılmıştır.

\subsection{Biçimi Farklı; Anlamı Aynı Olan Rusça Kökenli Sözcükler}

Çıldır Karapapak / Terekeme ağzı ile ilgili derlemelerde tespit edilen Rusça kökenli söz varlığı biçimce Rusçadan farklı; anlamca aynı olan madde başı sözcüklerden oluşmaktadır. Bu özellikteki madde başı sözcük sayısı 11'dir:

Tablo 13: Biçimi Farklı; Anlamı Aynı Olan Rusça Kökenli Sözcükler

\begin{tabular}{|c|c|}
\hline Madde Başı & Anlam \\
\hline dujun (dujin) & düzine \\
\hline garavat (krovat') & karyola \\
\hline gartof (kartofel) & patates \\
\hline$\dot{g} \iota r ı s ̧ a(k r ı s ̧ a)$ & çat1 \\
\hline neçellih'(naçelnik) & polis, asker \\
\hline pèc (pec') & soba \\
\hline pişġa (spiçka) & kibrit \\
\hline saldat (soldat) & asker \\
\hline simişġa (sem'eçko) & çekirdek \\
\hline vedre (vedró) & kova \\
\hline voj (vójji) & dizgin, at dizgini \\
\hline
\end{tabular}

Çıldır Karapapak / Terekeme ağzında tespit edilen az sayıdaki Rusça kökenli madde başı sözcüklerde biçimce farklılık; anlamca Rusça ile aynılık söz konusudur. Burada da fonetik değişmenin öne çıktığı görülür.

\subsubsection{Batı Kökenli Söz Varlığı}

Borçalı ve Çıldır Karapapak / Terekeme ağzı söz varlığının önemli bir kolunu da Batı kaynaklı sözcükler oluşturmaktadır. Özellikle teknolojik gelişme ve değişmelere bağlı olarak Türkçeye ve dolayısıyla ilgili ağızlara giren Batı kökenli sözcükler, Borçalı ve Çıldır 
yörelerinde anlam bakımından olmasa da söyleniş bakımından birbirinden farklı özellikler sergilemektedir. Bunda özellikle Borçalı Karapapak / Terekeme ağzında tespit edilen Batı kaynaklı söz varlığının büyük oranda Rusça üzerinden yöre ağzına girişi etkilidir. Bu noktada Çıldır Karapapak / Terekeme ağzıyla karşılaştırıldığında ilgili sözcüklerin söyleniş bakımından farklılığı belirgin bir şekilde ortaya çıkmaktadır. Borçalı ve Çıldır Karapapak / Terekeme ağzında tespit edilen Batı kökenli madde başı sözcükler, söylenişleri farklı; anlamları aynı olanlar, söylenişleri aynı; anlamları farklı olanlar, söyleniş ve anlamca aynı olanlar, söyleniş ve anlamca farklı olanlar, Borçalı'da olup Çıldır'da tespit edilemeyenler ve Çıldır'da olup Borçalı'da tespit edilemeyenler şeklinde sınıflandırılmıştır. Toplamda çoğu Fransızca asıllı 93 adet Batı kökenli madde başı sözcüğe yer verilmiştir.

\subsubsection{Söylenişleri Farklı; Anlamları Aynı Olan Batı Kökenli Sözcükler}

Batı kökenli söz varlığının Borçalı ve Çıldır Karapapak / Terekeme ağzındaki durumuna bakıldığında söylenişleri iki yörede ayrı olan; ancak anlamları aynı olan madde başı sözcüklerin sayısı çoğunluktadır. Yapılan taramalar sonucu bu özelliğe sahip madde başı sözcük sayısının 38 olduğu görülmüştür. Bu sözcüklerin ağırlıklı bölümü Fransızca kökenlidir (28); Fransızcayı sırasıyla İngilizce (4); Latince (3); İtalyanca (3) izlemektedir.

Tablo 14: Söylenişleri Farklı; Anlamları Aynı Olan Batı Kökenli Sözcükler

\begin{tabular}{|c|c|c|}
\hline \multicolumn{2}{|c|}{ Madde Başı } & \multirow{3}{*}{$\frac{\text { Anlam }}{(\text { Fr. autobus }) \text { otobüs }}$} \\
\hline Borçalı & Çıldır & \\
\hline $\begin{array}{l}\text { aftobus (Rus. } \\
\text { avtobus) }\end{array}$ & otobüs / otobos & \\
\hline agust (Rus. agust) & ă̆usdos & (Lat. august) ağustos \\
\hline akulletor & $a k \ddot{u}$ & (Fr. accumulateur) akümülatör, akü \\
\hline $\begin{array}{l}\text { alfafët (Rus. } \\
\text { alfavit) }\end{array}$ & alfabe & (Fr. alphabet $)$ alfabe \\
\hline ammünün & alamıyon & (İng. aluminium) aliminyum \\
\hline aprèl (Rus. aprel) & avril & (Ing. april) nisan \\
\hline arhiv (Rus. arxiv) & arşiv & (Fr. archives) arşiv, belgelik \\
\hline arkèsdir & orkesdıra & (Fr. orchestre) orkestra, müzik topluluğu \\
\hline asimilasya & asmilasyon & (Fr. assimilation) dönüştürme, değiştirme \\
\hline ensiḳlapédya & ansihlopedi & (Fr. encyclopédie) ansiklopedi \\
\hline fabrik / fabrèk & fabriga / bafirga & (It. fabbrica) fabrika \\
\hline gaminis & gominis & (Fr. communiste) komünist \\
\hline$\dot{g} a z \dot{e} t$ & gazète & (it. gazetta) gazete \\
\hline işbanah & lsbanah & (Rum. spinach) 1spanak \\
\hline kansèt & konsèr & (Ing. concert) konser \\
\hline makarnun & maḳarna / makarrama & (it. maccherone) makarna \\
\hline maşınisd & makinis & (Fr. machiniste) makinist \\
\hline may & mayıs & (Lat. may) may1s \\
\hline
\end{tabular}




\begin{tabular}{|c|c|c|}
\hline $\begin{array}{l}\text { muzikant (Rus. } \\
\text { muzikant) }\end{array}$ & müzüsyen & (Fr. musicien) müzisyen \\
\hline narmal & normal & (Fr. normal) olağan, olmas1 gereken \\
\hline $\begin{array}{l}\text { nömre (Rus. } \\
\text { nomer) }\end{array}$ & numara & (Lat. numeros) numara \\
\hline oksigèn & oksijen & (Fr. oxygene) oksijen \\
\hline pırafës & püröfösör & (Fr. professeur) profesör \\
\hline savèt & sovyet & (Fr. soviet) Sovyetler Birliği \\
\hline sintètika & sentetih & (Fr. synthétique) yapay \\
\hline tamatès & domatis & (Ing. tomato) domates \\
\hline tansiyon & tansuyon & (Fr. tension) tansiyon \\
\hline $\begin{array}{l}\text { tehnika (Rus. } \\
\text { téxnika) }\end{array}$ & tehnih & (Fr. technique) teknik \\
\hline tehnoloǵu & tehnoloji & (Fr. technologie) teknoloji \\
\hline tèlèvize / tèlèvizya & televizyon / tilvizyon & (Fr. téléfision) televizyon \\
\hline telfon & tilifon / dilfon & (Fr. téléphone) telefon \\
\hline ttrahdor & direhdor & (Fr. tracteur) traktör \\
\hline $\begin{array}{l}\text { ün ivèrstèt (Rus. } \\
\text { universitét) }\end{array}$ & ünüvèrsde & (Fr. université) üniversite \\
\hline
\end{tabular}

Borçalı ve Çıldır Karapapak / Terekeme ağzında tespit edilen Batı kökenli sözcüklerin büyük bölümünü iki yörede biçimce farklılık; anlamca aynılık gösteren madde başı sözcükler oluşturmaktadır. Bu farklılığın en büyük nedeni, Borçalı'da kullanılan Batı kökenli sözcüklerin Rusça üzerinden kopyalanmış olmasıdır.

\subsubsection{Söyleniş̧leri Aynı; Anlamları Farklı Olan Batı Kökenli Sözcükler}

Borçalı ve Çıldır Karapapak / Terekeme ağzında söylenişleri aynı; anlamları farklı olan Batı kökenli madde başı sözcük sayısı oldukça sınırlıdır. Bu özelliğe sahip toplam 2 sözcük tespit edilebilmiştir.

Tablo 15: Söylenişleri Aynı; Anlamları Farklı Olan Batı Kökenli Sözcükler

\begin{tabular}{|c|c|c|}
\hline \multirow{2}{*}{ Madde Başı } & \multicolumn{2}{|c|}{ Anlam } \\
\cline { 2 - 3 } & Borçalı & \multicolumn{1}{|c|}{ Çıldır } \\
\hline forma (İt. forma) & tip, şekil, biçim & okul giysisi \\
\hline măgaza (Fr. magasin) & $\begin{array}{c}\text { büyük dükkân, } \\
\text { market }\end{array}$ & kıyafet dükkânı \\
\hline
\end{tabular}

\subsubsection{Söyleniş ve Anlamca Aynı Olan Batı Kökenli Sözcükler}

Söyleniş ve anlamca aynı olan Batı kökenli madde başı sözcük sayısı, eldeki verilerde 1 olarak tespit edilebilmiştir.

Tablo 16: Söyleniş ve Anlamca Aynı Olan Batı Kökenli Sözcükler

\begin{tabular}{|c|c|}
\hline Madde Başı & Anlam \\
\hline fayıl (Fr. favori) & yüzün iki yanında çıkan saçın devamı niteliğindeki \\
& tüyler \\
\hline
\end{tabular}




\subsubsection{Söyleniş ve Anlamca Farklı Olan Batı Kökenli Sözcükler}

İlgili yörelerde söyleniş ve anlamca farklı olan Batı kökenli madde başı sözcük sayısı, eldeki verilere göre 1 olarak tespit edilebilmiştir.

Tablo 17: Söyleniș ve Anlamca Farklı Olan Batı Kökenli Sözcükler

\begin{tabular}{|c|c|c|c|}
\hline \multicolumn{2}{|c|}{ Madde Başı } & \multicolumn{2}{c|}{ Anlam } \\
\hline Borçalı & Çıldır & Borçalı & Çıldır \\
\hline $\begin{array}{c}\text { maşın (It. } \\
\text { macchina) }\end{array}$ & maşna & otomobil, otobüs & $\begin{array}{c}\text { makine, süt } \\
\text { makinesi }\end{array}$ \\
\hline
\end{tabular}

\subsubsection{Borçalı’da Olup Çıldır'da Tespit Edilemeyen Batı Kökenli Sözcükler}

Borçalı Karapapak / Terekeme ağzında tespit edilen Batı kökenli sözcüklerin büyük bir bölümünün Rusça üzerinden alındığı daha önce belirtilmişti. Aşağıdaki tabloda tarafımızca derlenen metinlerden hareketle Borçalı Karapapak / Terekeme Ağzında tespit edilip Çıldır Karapapak / Terekeme ağzında rastlanmayan Batı kökenli sözcüklere yer verilmiştir. Belirtilen özelliklere sahip Batı kökenli sözcüklerin sayısı 41'dir. Bu madde başı sözcüklerin büyük bölümü Fransızca kökenlidir (24). Bu sayıyı sırasıyla İngilizce (10); İtalyanca (3); Latince (3); Yunanca (1) takip etmektedir.

Tablo 18: Borçalı’da Olup Çıldır’da Tespit Edilemeyen Batı Kökenli Sözcükler

\begin{tabular}{|c|c|}
\hline Madde Başı & Anlam \\
\hline akadèmih'(Fr. académique) & en yüksek unvanlı üniversite hocası \\
\hline armatro (Fr. armature) & inşaat, beton demiri \\
\hline badron / padron (Fr. patrón) & bir tür silah; mermi \\
\hline banditizim (It. baditizm) & gasp; adam öldürme \\
\hline bityum (Ing. bitumen) & $\begin{array}{c}\text { katı veya yarı katı durumda, ağır hidrokarbon } \\
\text { karışımı }\end{array}$ \\
\hline biznis (İng. business) & iş; ticaret \\
\hline dèmog̀og் (Fr. démagogue) & çok konuşan; iftiracı \\
\hline donor (Fr. donneur) & gönüllü, yardımsever \\
\hline èpézot (Fr. épisode) & epizot, olay \\
\hline èpos (Fr. epopeé > Rus. epos) & destan \\
\hline faht (Ing. fact $>$ Rus. fakt) & gerçeklik; olgu; hadise \\
\hline familya (Ing. family) & aile; soyad 1 \\
\hline farmasya (Fr. formation) & yetişme; oluşum \\
\hline fata (Lat. fata) & duvak \\
\hline$\dot{\text { galèt (Fr. galette) }}$ & poğaça; peksimet \\
\hline gallektif (Fr. collectif) & ortakl1k \\
\hline gimnazè (Yun. gimnaziya) & klasik dillere yönelik eğitim veren okul \\
\hline infakt (Ing. infarct) & felç, inme \\
\hline inisttü / ünstüt (Fr. institut) & enstitü \\
\hline jurnalis $(F r$. journalist $)$ & gazeteci \\
\hline kampitur / komputer (Ing. computer) & bilgisayar \\
\hline kap italizm (Fr. capitalisme) & kapitalizm \\
\hline lekis (Fr. lexical) & söz dağarcı̆̆ 1 \\
\hline mayor (Lat. mayór) & binbaşı \\
\hline méditsiná (Fr. medicine $>$ Rus. meditsina) & tıp \\
\hline méhanih (Fr. mécanique) & makine mühendisi \\
\hline mevzelèh'(Fr. mausolée > Rus. mavzoley) & mozole, türbe, mezar \\
\hline
\end{tabular}




\begin{tabular}{|c|c|}
\hline minus (İng. minus) & eksi \\
\hline noyabır (Lat. noyábr) & kasım (ay) \\
\hline pürayékt (Fr. projet $>$ Rus. proyekt) & proje \\
\hline p̌rrizidènt (İng. president $>$ Rus. prezidént) & cumhurbaşkanı \\
\hline pirus (Ing. plus) & art1 \\
\hline rayon / rédyon / régyon (Fr. région > Rus. rayon) & ilçe, kaza \\
\hline sitratèjī (Fr. stratégique) & stratejik, önemli \\
\hline simol (Fr. symbole > Rus. simvol) & sembol, simge \\
\hline sinot (İt. senato $>$ Rus. senát) & sektörlerin toplandığ 1 yer \\
\hline sitatiska (Fr. statistique > Rus. statistika) & istatistik \\
\hline tapanim / toponim (Fr. toponomastique) & bir yerin, bölgenin adı \\
\hline
\end{tabular}

$\mathrm{Bu}$ tabloyu, hemen altında yer alan tablo ile birlikte ele alınacak olursa Borçalı'daki Batı kökenli sözcüklerin sayısının Çıldır'dan fazla olması, uzun zamandır Batı kültürünü yakından takip eden Türkiye sınırlarındaki Çıldır'ın bu durumu söz varlığına taşıyamadığı sonucunu ortaya koymaktadır. Buna karşın Borçalı'da Rusça üzerinden belirgin bir biçimde Batı kökenli söz varlığı girişinin gerçekleştiği görülür.

\subsubsection{6. Çıldır’da Olup Borçalı’da Tespit Edilemeyen Batı Kökenli Sözcükler}

Çıldır Karapapak / Terekeme ağzında olup Borçalı yöresinde tespit edilemeyen Batı kökenli sözcüklerin sayısı 8'dir. Bu sözcüklerden 3 tanesi Fransızca, 2 tanesi İtalyanca, 2 tanesi Almanca ve 1 tanesi de Macarcadır.

Tablo 19: Çıldır'da Olup Borçalı'da Tespit Edilemeyen Batı Kökenli Sözcükler

\begin{tabular}{|c|c|}
\hline Madde Başı & Anlam \\
\hline firğın (Fr. fourgon) & at arabas1 \\
\hline gadana (Mac. katona) & bir cins iri at \\
\hline ġaput (Fr. capote) & kaput; asker paltosu \\
\hline irmatizma (İt. reumatismo) & romatizma \\
\hline kasatura (İt. cacciatora) & süngü; bıçak \\
\hline mang்a / mañ் a (Alm. manga) & on askerden oluşan birlik \\
\hline mosg்of (Alm. moskowiter) & Rus \\
\hline payton (Fr. phaeton) & fayton \\
\hline
\end{tabular}

\subsubsection{Diğer Alıntı Sözcükler}

Borçalı ve Çıldır Karapapak / Terekeme ağzında yukarıda tasnif edilen söz varlığı unsurlarının dışında kalan birtakım alıntı madde başı sözcükler de mevcuttur. Bu sözcükler arasında 2 Moğolca; 2 Ermenice; 1 Gürcüce ve 1 Slavca sözcüğe rastlanmıştır. Bunlardan 3 tanesi Çıldır'da; 2 tanesi Borçalı'da tespit edilmiştir. 1 adet madde başı sözcük ise her iki yörede ortaktır. Söz konusu sözcüklerden 3 tanesi kaynak dildeki biçim ve anlamıyla kullanılırken 3 tanesi yalnız anlam bakımından kaynak dille örtüşmektedir. 
Tablo 20: Diğger Alıntı Sözcükler

\begin{tabular}{|c|c|}
\hline Madde Başı & Anlam \\
\hline cèyran (Moğ. cegeren) & ceylan (Borçalı) \\
\hline çermih́' (Erm. çermug) $^{9}$ & şifalı su, kaplıca (Çıldır) \\
\hline lazut (Erm. lazud) $)^{10}$ & mısır (Çıldır) \\
\hline manat (Sl. manat) & Azerbaycan'ın para birimi (Çıldır) \\
\hline maral (Moğ. maral) & ceylan (Borçalı / Çıldır) \\
\hline lari (Gür. lari) & Gürcistan'ın para birimi (Borçalı) \\
\hline
\end{tabular}

\section{Sonuç}

Borçalı ve Çı1dır Karapapak / Terekeme ağzındaki alıntı sözcüklerin değerlendirildiği bu çalışma, Arapça ve Farsça sözcük yoğunluğunu; Borçalı'da Rusça ve Farsça alıntıların Çıldır'a göre daha yaygın olduğunu; Batı kökenli sözcüklerin Borçalı'da Rusça üzerinden kopyalandığını göstermektedir.

Borçalı ve Çıldır'da yapılan saha çalışmaları sonucu söz varlığının önemli bir bölümü olarak incelenen alıntı sözcüklerin, ait oldukları dillerin farklılığına göre tasnif edilerek belirtilmesi, ilgili yörelerin her ikisi veya sadece biri üzerinde yapılacak daha kapsamlı söz varlığı çalışmalarında araştırmacıların doğrudan veya dolaylı olarak yararlanabilmelerine olanak verecektir. Burada gösterilen sözcüklerin ait oldukları dilin belirtilmesi, araştırmacıların zamandan tasarruf etmelerini sağlayacak, sayısal veriler ise alıntılanan sözcüklerin kaynak dillere göre hedef dilin ağzındaki yoğunluk durumunu gösterecektir.

Söz konusu çalışma, ilgili yörelerin tarihî, siyasi, sosyal ve kültürel özellikleri göz önünde bulundurularak aynı Türk boyunun farklı coğrafi sınırlardaki ağızları ile birbirine sınır olan ağız yörelerinde eş zamanlı olarak veya aynı ağız yöresinden farklı dönemlerde derlenmiş metinler esasında art zamanlı olarak benzer şekilde veya geliştirilerek uygulanabilir. Bu durum, bir toplumun sosyal ve kültürel yapısı, komşularıyla ilişkileri ile gelenek ve göreneklerini tespit etme araçlarından biri olan söz varlığının eş zamanlı veya art zamanlı olarak ortaya çıkarılmasını sağlayacaktır.

\section{Kaynaklar}

AKSAN, D. (2006). Türkçenin Sözvarlı̆̆ı. Ankara: Engin Yayınevi.

AKSOY, Ö. A. (1974). Cumhuriyet Çağı Türkçesi IV. Türk Dili, 271, 541-544.

ALIMOVA, J. (2011). Türkiye Türkçesi Ağızları ile Kırgız Türkçesinin Söz Varlığı Açısından Karşılaş̧tırlması. Yayımlanmamış Doktora Tezi, İzmir: Ege Üniversitesi Türk Dünyası Araştırmaları Enstitüsü.

ALYILMAZ, S. (2002). Borçalı (Gürcistan) Karapapaklarının / Terekemelerinin Tarihine Dair. Yeni Türkiye Dergisi (Türkoloji ve Türk Tarihi Araştırmaları Özel Sayısı), 43, 288-291.

\footnotetext{
${ }^{9}$ Ölmez (2009: 243), Dankoff’a dayanarak bu sözcüğün Ermenice olduğunu belirtmiştir.

${ }^{10}$ Ölmez (2009: 265), Dankoff' a dayanarak bu sözcüğün Ermenice olduğunu belirtmiştir.
} 
ALYILMAZ, S. (2003). Borçalılı Bilim Adamı, Eğitimci, Şair Valeh Hacılar: Hayatı-SanatıŞiirleri. Ankara: Devran Yayınları.

BALA, M. (1977). Karapapak. Íslam Ansiklopedisi, VI. İstanbul: Milli Eğitim Basımevi, 330331.

CAFEROĞLU, A. (1969). Milletlerarası Kültür Sözlüğündeki Bazı Türkçe Unsurlar. Türk Dili Araştırmaları Yıllı̆̆ Belleten, 25-43.

DEMIR, N. (2013). Ankara Örneğinde Ă̆ızların Belgelenmesi. Ankara: TDK Yayınları.

ERCILASUN, A. B. (1995). Yabanc1 Dille Eğitim. Türk Dili, 526, 1072-1075.

ERCiLASUN, A. B. (2002). Kars İli Ağızları. (2. Baskı). Ankara: TDK Yayınları.

GEMALMAZ, E. (2010). Dilde Anarşi ve Türk Dilinde Anarşi. Türkçenin Derin Yapısı. Ankara: Belen Yayınc1lık, 31-52.

GEMALMAZ, E. (2010). Türk Lengüistiği ve Kültür Alışverişi Meseleleri. Türkçenin Derin Yapısl. Ankara: Belen Yayınc1lık, 521-552.

GÜNEŞ, B. (2013). Borçalı (Gürcistan) Karapapak / Terekeme Ağzı (İnceleme-MetinlerSözlük). Yayımlanmamış Doktora Tezi, Trabzon: Karadeniz Teknik Üniversitesi Sosyal Bilimler Enstitüsü.

KARAAĞAÇ, G. (1997). Alıntı Kelimeler Üzerine Düşünceler. Türk Dili, 552, 499-510.

KARAAĞAÇ, G. (1998a). Türkçenin Komşu Dillere Verdiği Giyim Kuşam Kültürüyle İlgili Kelimeler. Türk Dili, 5, 361-387.

KARAAĞAÇ, G. (1998b). Türkçenin Komşularına Verdiği Beslenme Kültürüyle İlgili Kelimeler. Türk Dili, 564, 476-495.

KARAAĞAÇ, G. (2008). Türkçe Verintiler Sözlüğü. Ankara: TDK Yayınları.

KARAHAN, L. (1996). Anadolu Ağızlarının Sinıflandırılması. Ankara: TDK Yayınları.

KARAHAN, A. (2008). Et-Tuhfetu'z-Zekiyye Fi'l-Lugati't-Türkiyye'de Alet İsimleri. Kültür Üniversitesi I. Uluslararası Türk Dili ve Edebiyatı Öğrenci Kongresi Bildirileri, (11-13 Eylül 2006, İstanbul), İstanbul: Kültür Üniversitesi Yayınları, 51-62.

KORKMAZ, Z. (2005). Batı Kaynaklı Yabancı Kelimeler ve Dilimiz Üzerindeki Etkileri. Türk Dili Üzerine Araştırmalar, I. Ankara: TDK Yayınları, 948-959.

KORKMAZ, Z. (2007). Türkiye Türkçesinde Yazı Diline Girmiş Günlük Yaşamla İlgili Alıntı Sözler ve Ekler. Türk Dili Üzerine Araştırmalar, III. Ankara: TDK Yayınları, 487-496.

KORKMAZ, Z. (2007). Gramer Terimleri Sözlüğ̈̈. (3. Baskı). Ankara: TDK Yayınları.

ÖLMEZ, M. (2009). Türkiye'deki Ağız Çalışmaları ve Dizin Bölümleri. Türk Dilleri Araştırmaları, 19, 223-304.

ŞİRELIYEV, M. (1962). Azerbaycan Dialektologiyasının Esasları. Bakı: Azerbaycan Devlet Tedris Pedagoji Edebiyyatı Neşriyyatı.

ZÜLFIKAR, H. (1996). Dilde Yozlaşma (I). Türk Dili, 529, 3-5.

ZÜLFIKAR, H. (1997). Dil Bayramında Türkçeye Genel Bir Bakış. Türk Dili, 551, 400-404.

\section{Çeviri Yazı İşaretleri}

á $\quad$ : a-e arası ünlü

ä $\quad$ : açık e ünlüsü 
í $\quad$ : 1-i arası ünlü

ú $\quad$ : u-ü arası ünlü

è $\quad$ : e-i arası ünlü (kapalı e ünlüsü)

i $\quad$ : : 1-u arası ünlü

$\overline{\mathbf{a}} \quad$ : uzun a ünlüsü

$\overline{\mathbf{e}} \quad$ : uzun e ünlüsü

i $\quad$ : uzun i ünlüsü

ӧ $\quad$ : uzun ö ünlüsü

I $\quad$ : k1sa 1 ünlüsü

乏 $\quad$ : k1sa i ünlüsü

$\dot{\mathbf{g}} \quad$ : arka damak g sesi

g $\quad$ : ön damak g sesi (yalnız kalın ünlülerle)

h $\quad$ : arka damak sızıcı h sesi

h́ : ön damak sızıcı h sesi

k $\quad$ : arka damak k sesi

k $\quad$ : ön damak k sesi (yalnız kalın ünlülerle)

n $\quad$ : damak n'si

Ç : ç-c arası ses

B $\quad$ : $p$-f arasi ses

T : $\quad$ t-d arasi ses

h $\quad$ : düşme eğilimi gösteren $\mathrm{h}$ sesi 